\title{
Mercury Pollution Exploration in Latvia with High- Sensitivity Zeeman Atomic Absorption Spectrometry
}

\author{
Egils Bogans ${ }^{1}$, Zanda Gavare ${ }^{2}$, Anda Svagere ${ }^{3},{ }^{1-3}$ Institute of Atomic Physics and Spectroscopy, University of Latvia, \\ Rita Poikane, Latvian Institute of Aquatic Ecology, Janis Skudra, Institute of Atomic Physics and Spectroscopy, \\ University of Latvia
}

\begin{abstract}
This research presents $\mathrm{Hg}$ pollution measurements performed in Latvia with sensitive method using Zeeman AAS analyzer RA-915+ and necessary attachments. Air in Riga city and water samples from a number of rivers and lakes of Latvia were analyzed for presence of low-level $\mathrm{Hg}$ concentrations. Ombrotrophic bog peat was analyzed to get insight into longterm trends. Environment in the sites sampled is relatively clean according to the results obtained, but there are local spots of pollution.
\end{abstract}

Keywords - Mercury in environment, mercury monitoring, mercury background in Latvia, Zeeman atomic absorption spectroscopy

\section{INTRODUCTION}

Although mercury is an element naturally present in the Earth's crust, and, owing to its unique physical properties, it is widely used to manufacture many different products like measurement devices, light sources, medical and cosmetic substances, etc., it is also a dangerous heavy metal. In combination with other inorganic and organic chemicals, mercury forms various compounds, from which methylmercury is widely recognized as the most toxic.

Naturally mercury is in a bound state, mostly as a mineral cinnabar, however it can be released as a result of various natural and anthropogenic activities. There are continuous ongoing processes in nature, which cause transformations between different forms of mercury [1], thus in order to assess harm to the environment and human health, it is important to gather information about all stocks and their distribution.

When considering the presence of mercury somewhere, one might think in two different categories - about the immediate short-term effects of this metal, and about the longer-lasting but not so obvious changes caused. In the former case, we speak about directly harmful concentrations of mercury and about time frames from hours to a few years, depending on the particular compound and the type of exposure. In the latter case we shall consider even small concentrations, with changing trends pointing toward possible problems: e.g., even minuscule amounts of mercury bio-accumulate through the food chain, as a result potentially becoming dangerous. Therefore, it is important to perform both short-term monitoring of mercury to preserve our health in current time and place, and long-term monitoring to take care of our future.

The long-term monitoring of mercury background concentration changes needs measurements with a resolution significantly better than is usually required in official regulatory documents. Mercury background concentration in atmosphere is typically just few $\mathrm{ng} / \mathrm{m}^{3}$ (e.g., in [2] the annual average total gaseous mercury (TGM) concentration in the European and North American troposphere is estimated being between 1.5 and $1.7 \mathrm{ng} / \mathrm{m}^{3}$, in [3] the 4-year average concentrations between 1.3 and $1.9 \mathrm{ng} / \mathrm{m}^{3}$ of TGM were measured, etc.). European Community Strategy Concerning Mercury [4] provides for establishment of Global Mercury Monitoring Network (GMOS) with the appropriate monitoring capacity. At the same time, the limits defined by the governmental regulations in Latvia are significantly less demanding - the occupational exposure limit set at 0.05 $\mathrm{mg} / \mathrm{m}^{3}$ [5] ( $8 \mathrm{~h}$ exposure x 5 working days per week) and air quality target at $1 \mu / \mathrm{m}^{3}$ [6] (24-hour average).

Similar, if somewhat less pronounced, situation exists with mercury in fresh water. E.g., the concentrations of mercury in South American lakes and rivers, listed in [7], range from 0.6 to $10.9 \mathrm{ng} / \mathrm{l}$ and represent different environmental settings. Mercury concentrations in 58 rivers in Maine, USA, were measured in another research [8] to range from values below the detection limit of equipment used and up to $7.01 \mathrm{ng} / \mathrm{l}$, and averaged at $1.80 \pm 1.29 \mathrm{ng} / \mathrm{l}$. In the regulation in Latvia [9], the allowed yearly average concentration is defined at $0.05 \mu \mathrm{g} / \mathrm{l}$ and the maximum permitted concentration at $0.07 \mu \mathrm{g} / \mathrm{l}$.

Authors of this paper are involved in improvement and development of components for new sensitive mercury measurement methods, and, as a practical outcome, are gathering measurement data from different objects in Latvia. In this work, we present some efforts made during the last six years, which contribute to short- and long-term monitoring of mercury concentrations in Latvia.

\section{II.HG CONCENTRATION MEASUREMENT EQUIPMENT USED}

The core device used in all measurements of mercury concentration was the atomic absorption analyzer Lumex RA-915+. The principle of functioning of the analyzer is based on Zeeman atomic absorption spectrometry (AAS) with a high-frequency modulation of polarization. The differential method of AAS is implemented using the direct Zeeman Effect - the selectivity and stability of measurements is obtained by comparing the intensities of two beams, which propagate through the same path and have different but very close wavelengths - the difference is about the width of an atomic absorption line [10].

Usually, the measurements are performed in real-time, giving a concentration reading once per second. The detection 
limit of RA-915+, when measuring $\mathrm{Hg}$ concentration in the air in the continuous flow mode, is $1-2 \mathrm{ng} / \mathrm{m}^{3}$ (measuring over longer intervals allows to decrease it to lower values).

Due to its principle of operation, the RA-915+ analyzer measures gaseous elemental mercury $\left(\mathrm{Hg}^{0}-\mathrm{GEM}\right)$, which chemically is not exactly the same as TGM, but it has been proven in a number of papers, that, except close to the sources of other mercury species in the air, the values of GEM and TGM can be considered being equal. This is recognized by the BS EN 15852:2010 standard [11], and the analyzer completely satisfies the requirements of this standard.

Solid samples were analyzed, complementing the RA-915+ analyzer with a pyrolysis attachment RP-91C - mercury contained in the sample is atomized by pyrolysis, and the emitted mercury amount is read by RA-915+ as an integratedover-the-time absorption signal. The $\mathrm{Hg}$ concentration per mass unit of sample is calculated applying a calibration coefficient obtained from the analysis of the reference standard with a known $\mathrm{Hg}$ content. Analysis time is 1-2 minutes per sample.

Mercury determination in liquid samples was performed, using RA-915+ analyzer with RP-91 attachment; the principle of operation is based on cold vapor atomic absorption spectroscopy - CV-AAS; similarly to solid samples, the emitted mercury amount is read by RA-915+ as an integratedover-the-time absorption signal. Analysis time is $\sim 1$ minute per sample (not including chemical preparation).

\section{MERCURY CONCENTRATION MEASUREMENTS IN THE AIR IN RIGA}

Mercury concentration measurements in air, as presented in this work, are an example of short-term monitoring (as opposed to voluminous, statistically analyzable data collection). The aim of the measurements was to detect the presence of mercury and to determine the possibility of immediate threat.

\section{A. Measurement procedure}

Combining the RA-915+ analyzer with the PC-connected GPS receiver, a portable system, capable to collect a $\log$ of real-time $\mathrm{Hg}$ concentrations in air for known coordinates, was constructed. Air samples are continuously collected by the analyzer inlet pipe, which is located $\sim 1.5 \mathrm{~m}$ above ground in a car window, if measuring while driving, or the inlet pipe is brought $2-10 \mathrm{~cm}$ close to the point of interest, if measuring during a walk-around.

The accuracy and relevance of the $\mathrm{Hg}$ concentrations measured are mostly limited by the environmental conditions - topology and wind, with the lower bound set by an analyzer detection limit of $1-2 \mathrm{ng} / \mathrm{m}^{3}$. The accuracy of location coordinates is determined by the accuracy of the GPS receiver used (Magellan Meridian Color or Magellan eXplorist 500), said to be $\pm(3-10) \mathrm{m}$.

\section{B. Measurement results and analysis}

During the years 2005-2011, a number of routine measurement sessions were performed, recording location- associated mercury concentrations, searching and finding spots of mercury pollution in different places in the city of Riga. The results of measurements are presented in the earlier works [12-17].

It can be observed from the collected data that, depending on the season and time of day, the background level of $\mathrm{Hg}$ in the open air in Riga varies in the range between $2-5 \mathrm{ng} / \mathrm{m}^{3}$. With few exceptions, $\mathrm{Hg}$ concentrations in the open air in the areas of local pollution spots usually do not exceed $20-40 \mathrm{ng} / \mathrm{m}^{3}$.

Standing out of normal background and small transient pollution spots is the mercury spill on Spilves street in Riga in 2005. On $17^{\text {th }}$ of June $20050.5 \mathrm{~kg}$ of mercury were spilled over a $30 \mathrm{~m}^{2}$ area. The place was cleaned-up, though due to the lack of chemicals final washing was not completely done [18]. Over the years 2005-2011 a number of air samples' measurement sessions were performed on the site. The maximum concentrations of $\mathrm{Hg}$ registered in the open air at the site are presented in Figure 1.

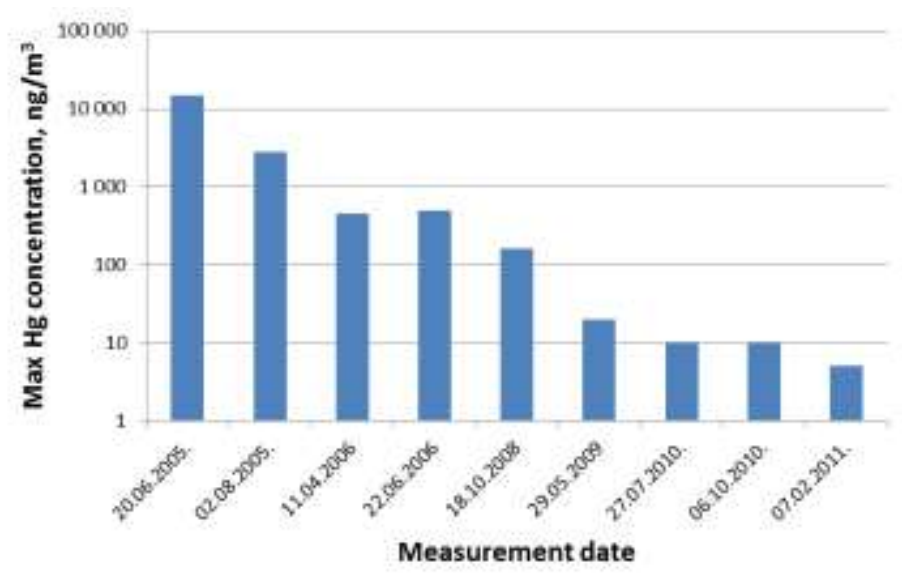

Fig. 1. Determined maximum Hg concentrations in air over Spilves spill site.

As one can see, after the spill the background level was reached again only within a period of about six years.

While mercury concentration in the air decreased over the time, it was observed that not all of the dangerous metal had been evaporated - significant presence of it could be seen in the nearby waste water manhole. The maximum concentrations of $\mathrm{Hg}$ registered in the air at just-opened manhole are presented in Table 1.

TABLE 1

MAXIMUM REGISTERED HG CONCENTRATION IN THE AIR AT THE WASTE WATER MANHOLE NEAR THE SPILVES STREET SPILL SITE

\begin{tabular}{|l|l|}
\hline Measurement date & Max $\mathbf{H g}$ concentration, $\mathbf{n g} / \mathbf{m}^{\mathbf{3}}$ \\
\hline April 11, 2006 & 77500 \\
\hline July 2, 2007 & 88000 \\
\hline May 29, 2009 & 60000 \\
\hline
\end{tabular}




\section{MERCURY CONCENTRATION MEASUREMENTS IN SAMPLES} OF NATURAL WATERS

Mercury concentration measurements in water, as presented in this work, also represent short-term monitoring. Mercury concentrations at particular times were determined in several Latvian river and lake water samples.

\section{A. Reagents}

All chemicals used were of analytical grade. The working solutions were prepared according to recommendations of [1921], and a brief summary is given below.

A reducing $\mathrm{SnCl}_{2} \cdot 2 \mathrm{H}_{2} \mathrm{O}$ solution in $\mathrm{NaOH}$ was prepared by dissolving $10 \mathrm{~g}$ of $\mathrm{NaOH}$ (Sigma-Aldrich, puriss. p.a., $\left.\mathrm{Hg} \leq 5 \cdot 10^{-6} \%\right)$ in $50 \mathrm{ml}$ of distilled water, then gradually adding $6 \mathrm{~g}$ of $\mathrm{SnCl}_{2}$ (Merck, for analysis, $\mathrm{Hg} \leq 1 \cdot 10^{-6} \%$ ) dissolved in distilled water, and proceeding with the addition of $10 \mathrm{~g}$ of $\mathrm{NaOH}$, and diluting to $100 \mathrm{ml}$ with distilled water.

A $0.033 \mathrm{~mol} \cdot 1^{-1} \mathrm{KBrO}_{3}$ and a $0.2 \mathrm{~mol} \cdot \mathrm{l}^{-1} \mathrm{KBr}$ solutions were prepared daily from the corresponding reagents $\left(\mathrm{KBrO}_{3}-\right.$ Fluka, puriss. p.a.; $\mathrm{KBr}$ - Sigma-Aldrich, puriss. p.a., $\mathrm{Hg} \leq 0.1 \mathrm{mg} / \mathrm{kg})$ and mixed in a $1: 1$ proportion $\left(\mathrm{KBr} / \mathrm{KBrO}_{3}\right.$ solution).

A $100 \mathrm{~g} / \mathrm{l}$ hydroxylamine hydrochloride $\left(\mathrm{NH}_{2} \mathrm{OH} \cdot \mathrm{HCl}\right)$ was prepared daily (Merck, puriss. p.a., $\mathrm{Hg} \leq 0.01 \mathrm{mg} / \mathrm{kg}$ ).

A potassium permanganate solution was prepared by dissolving $5 \mathrm{~g}$ of $\mathrm{KMnO}_{4}$ (Sigma-Aldrich, puriss .p.a., $\mathrm{Hg} \leq 5 \cdot 10^{-6} \%$ ) in $100 \mathrm{~mL}$ of distilled water.

A potassium persulfate solution was prepared by dissolving $5 \mathrm{~g}$ of $\mathrm{K}_{2} \mathrm{~S}_{2} \mathrm{O}_{8}$ (Fluka, puriss. p.a.) in $100 \mathrm{~mL}$ of distilled water.

A potassium dichromate $4 \%$ solution was prepared by dissolving $4 \mathrm{~g}$ of $\mathrm{K}_{2} \mathrm{Cr}_{2} \mathrm{O}_{7}$ (Fluka, puriss. p.a.) and diluting to $100 \mathrm{ml}$ with distilled water.

A $9.954 \pm 0.053 \mathrm{mg} / \mathrm{g} \mathrm{Hg}^{2+}$ certified standard stock solution was obtained from the National Institute of Standards \& Technology (NIST SRM 3133 Mercury Standard Solution). The experiments were done using a $50 \mathrm{ng} \mathrm{l}^{-1} \mathrm{Hg}$ standard solution. Working solutions were prepared daily from the stock solution by serial dilution with distilled water.

Other chemicals that were used in pretreatment of samples were $\mathrm{HCl}\left(37 \%\right.$, Fluka, puriss. p.a., $\left.\mathrm{Hg} \leq 5 \cdot 10^{-7} \%\right), \mathrm{HNO}_{3}(65$ $\%$, Sigma-Aldrich, puriss. p.a., $\mathrm{Hg} \leq 0.005 \mathrm{mg} / \mathrm{kg}$ ) and $\mathrm{H}_{2} \mathrm{SO}_{4}$ (95-97\%, Fluka, puriss. p.a., $\mathrm{Hg} \leq 5 \cdot 10^{-7} \%$ ).

\section{B. Sample collection}

The water was collected from the lakes Alūksne, Babīte (2 sites), Burtnieks (2 sites), Dridzis, Engure, Kaņieris, Ķī̌sezers, Liepāja (2 sites), Rāzna, Sīvers and Sloka, and from the rivers Slocene, Lielupe and Venta. Depth of sample collection varied between sampling sites from 0.5 to $1.5 \mathrm{~m}$.

All water samples immediately after the collection were transferred into in borosilicate bottles with tight screw caps and acidified using $\mathrm{HNO}_{3}$ ( $1 \mathrm{ml}$ of acid to $100 \mathrm{ml}$ of sample), packed into sealed plastic bags and stored in a refrigerator until analysis.

The samples were not filtered, the total amount of mercury (including particulate-bound) was measured to obtain the maximum carried $\mathrm{Hg}$ concentration values. Accordingly, for filtered samples, the mercury concentration values would not be higher than for the ones measured in this work.

\section{Sample pretreatment and measurement procedures}

Water samples were analyzed for $\mathrm{Hg}$ using two pretreatment (oxidation) methods [19-21].

Method 1: $3.5 \mathrm{ml}$ concentrated $\mathrm{H}_{2} \mathrm{SO}_{4}, 1 \mathrm{ml}$ concentrated $\mathrm{HNO}_{3}, 2 \mathrm{ml} \mathrm{KMnO}$ solution and $1.5 \mathrm{ml} \mathrm{K} \mathrm{S}_{2} \mathrm{O}_{8}$ solution were added to $35 \mathrm{ml}$ of sample, and then diluted to $50 \mathrm{ml}$ by distilled water. Then the samples were stored at room temperature in dark for at least 15 hours.

Method 2: $7.5 \mathrm{ml}$ of $\mathrm{HCl} 4 \mathrm{~mol} \cdot \mathrm{l}^{-1}, 1 \mathrm{ml}$ of $\mathrm{KBr} / \mathrm{KBrO}_{3}$ solution and $1.5 \mathrm{ml}$ of distilled water were added to $40 \mathrm{ml}$ of samples. Then the samples were stored for about 1-2 hours.

Method 1 is more demanding in terms of procedures and the processing time of a sample is longer (if sample heating during the pretreatment is not used, as in this research), but it gives better detection/quantification limits in comparison to Method 2 [22]. Method 2 is still kept in use due to its suitability for immediate out-in-the-field analysis of water samples without a need for sample preservation.

After oxidation, the sample was pre-reduced with $\mathrm{NH}_{2} \mathrm{OH} \cdot \mathrm{HCl}$. Then the sample $(5 \mathrm{ml})$ was transferred to a reduction flask, and the ionic $\mathrm{Hg}$ in the sample was reduced with $\mathrm{SnCl}_{2}(2 \mathrm{ml})$ to convert $\mathrm{Hg}$ (II) to volatile $\mathrm{Hg}(0)$. The $\mathrm{Hg}(0)$ was separated from the solution by bubbling air through the sample. The $\mathrm{Hg}$ passes into an air stream that carries the released $\operatorname{Hg}(0)$ into the cell of the RA-915+ analyzer for detection.

\section{Quality assurance procedures}

All glassware before sample collection and processing is controlled for contamination with $\mathrm{Hg}$, using a slightly modified procedure described in [19] $\left(\mathrm{SnCl}_{2} \cdot 2 \mathrm{H}_{2} \mathrm{O}\right.$ is added to rinsing solution).

Background mercury concentration in laboratory air is periodically controlled, using real-time $\mathrm{Hg}$ measurement capabilities of RA-915+ analyzer. Values range from 3 to $10 \mathrm{ng} / \mathrm{m}^{3}$ without fast changes.

Together with lake and river water samples, blanks of distilled water were handled and prepared in the same way to account for the contamination during all stages of sample treatment.

In about half of cases two independent samples are collected for a single sampling site, and for each sample two replicates are processed independently starting from pretreatment step. For each replicate, 2-3 measurements are made.

The detection and quantification limits for each of both processes, corresponding to different pretreatment methods, were verified according to [23]. The parameters obtained are given in Table 2.

The quality of reagents used was determined as the limiting factor for performance of Method 2 [22]. 
TABLE 2

MDL AND LOQ EVALUATION OF METHODS USED

\begin{tabular}{|l|l|l|}
\hline Parameter & Method 1 & Method 2 \\
\hline Standard deviation & 0.1 & 0.6 \\
\hline Method detection limit (MDL), ng/l & 0.3 & 1.6 \\
\hline Signal/noise ratio & 8.5 & 8.8 \\
\hline Level of quantification (LOQ), ng/l & 1.2 & 5.5 \\
\hline Average Recovery, \% & 99.24 & 96,71 \\
\hline
\end{tabular}

\section{E. Measurements results and analysis}

Figure 2 shows the measurement results obtained. Values below MDL are not shown in the graph; therefore, Alūksne, Babīte (site 1), Engure and Liepāja (site 2) lake, and Venta river sites do not appear on the graph at all.

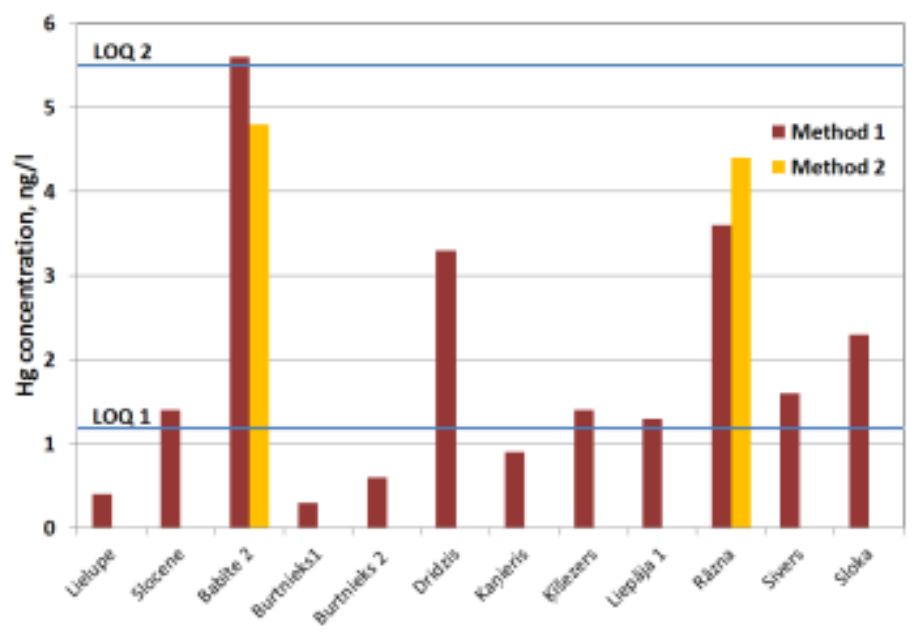

Fig. 2. Determined $\mathrm{Hg}$ concentration in natural water samples.

One can see that all the values measured are significantly below the threshold set in [9].

12 of 16 sites had mercury concentrations above MDL of Method 1, of which 8 qualified for being quantified.

Mercury concentrations just in two cases reached the level detectable by Method 2 - in Babīte (site 2) and Rāzna lakes. None of them could be accepted as quantified by that method.

The determined concentrations are in good agreement with mercury concentrations usually observed in non-polluted waters [24].

It should be noted that, because no sample filtering was applied, the actual concentrations of dissolved mercury could be even lower.

\section{V.HG MEASUREMENTS IN PEAT}

Ombrotrophic bogs are isolated from the influence of local ground water and surface water, and receive their inorganic content by atmospheric deposition only; therefore, the peat from such bogs can be used to study the long-term historical trend of atmospheric metal deposition $[25,26]$.

\section{A. Sample collection}

Peat samples and their age data were generously provided by the Faculty of Geography and Earth Sciences, University of Latvia.

Mercury was analyzed in several peat samples from two ombrotrophic peat bogs located in Latvia (Dižais Veikenieks and Dzelve). Vertical columns of peat were collected and cut into horizontal layers representing different ages. The sample age for a number of layers was determined using ${ }^{14} \mathrm{C}$ dating. The age of other layers was obtained by interpolation.

\section{B. Hg measurement procedure}

The mercury distribution profile by age was determined by analyzing samples from different layers of peat.

For each measurement, a weighted sample of air-dried peat (5-30 mg) is taken into an injection spoon of the RP-91C attachment. Integration of the analytical signal by RA-915+ is turned on and the injection spoon is placed into the attachment for pyrolysis.

No mechanical homogenization is applied to samples; instead, a number of measurements are made for different parts of samples. Non-even distribution of mercury in the sample, if applicable, shows up as an increased dispersion of the values measured.

\section{Measurement results and analysis}

Measured mercury concentrations in the peat bog Dzelve range from 13 to $60 \mu \mathrm{g} / \mathrm{kg}$, in the peat bog Dižais Veikenieks - from 55 to $190 \mu \mathrm{g} / \mathrm{kg}$.

In the peat bog Dzelve (Fig.3), mercury concentration smoothly decreases with the increasing depth (age). At the surface, $\mathrm{Hg}$ concentration was determined to be about 60 $\mu \mathrm{g} / \mathrm{kg}$.

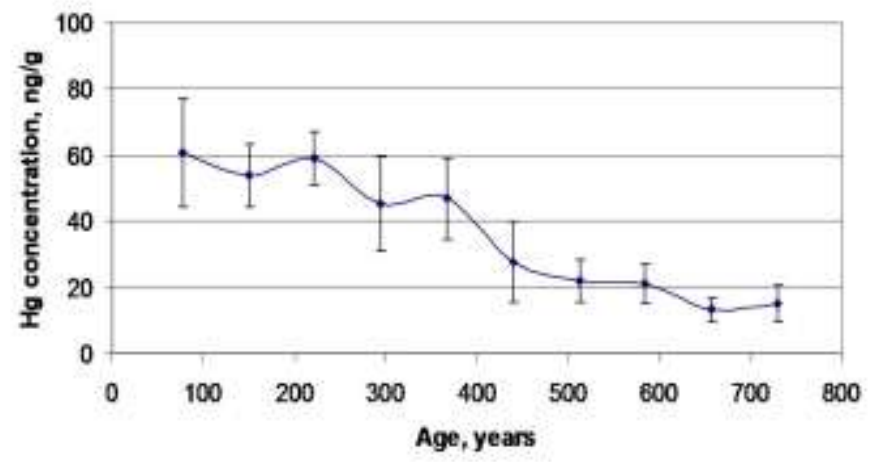

Fig. 3. Mercury distribution profile in the peat's layer with thickness of $50 \mathrm{~cm}$ in Dzelves peat bog.

In the peat bog Dižais Veikenieks, the highest mercury concentration also was determined at the surface (about $190 \mu \mathrm{g} / \mathrm{kg}$ ), then it decreases, but in the oldest layers increased concentrations are observed again. Unfortunately, due to the weak resolution of time axis data it is not possible to identify the source of peaks (usually volcanic eruptions, which is the largest primary non-anthropogenic source of mercury, can be seen in historic mercury concentration records). Such peaks 
cannot be observed in Dzelve bog data due to the limited time span of its samples.

Mercury concentrations in the measured samples range from approximately 10 to $200 \mathrm{ng} / \mathrm{g}$, which roughly corresponds to the concentrations observed elsewhere [25-27].

The increase of mercury concentration in the youngest layers of peat might be attributed to the beginning of industrialization, though the better time resolution might be desired for more certain conclusions.

\section{CONCLUSIONS AND DISCUSSION}

The background concentration of $\mathrm{Hg}$ in the air in Riga is determined being within the range of $2-5 \mathrm{ng} / \mathrm{m}^{3}$. There is no data from other authors available about the mercury concentration in the ambient air in Latvia. The obtained value is larger than the overall background concentration mentioned in [2], but considering that it is an urban area, where mercury concentrations are typically higher, it seems to be in good agreement with the data obtained elsewhere in the world. E.g., in downtown Toronto TGM concentrations ranged from 1.3 to $50 \mathrm{ng} / \mathrm{m}^{3}$ with values $>3 \mathrm{ng} / \mathrm{m}^{3}$ seen more frequently than in rural areas; TGM averaged at $3.6 \pm 2.9 \mathrm{ng} / \mathrm{m}^{3}$ with maximum $22 \mathrm{ng} / \mathrm{m}^{3}$ at the downtown Chicago site and $2.2 \pm 0.7 \mathrm{ng} / \mathrm{m}^{3}$ at the rural site in Lake Michigan Basin [28]; $4.4 \pm 2.7 \mathrm{ng} / \mathrm{m}^{3}$ TGM had been measured in downtown Baltimore [29]; at lake Balaton concentrations between 0.4 and $5.9 \mathrm{ng} / \mathrm{m}^{3}$ with higher concentrations during the day time had been measured; TGM averaged at $3.4 \mathrm{ng} / \mathrm{m}^{3}$ with maximum hourly mean concentration of $37.1 \mathrm{ng} / \mathrm{m}^{3}$ at Champ sur Drac, a suburban site of Grenoble in southern east France [30].

Authors of this paper appreciate the plan to establish permanent monitoring stations in Riga and Liepaja for control of mercury concentration in the air [31], and hope that the resolution of data obtained therein will be sufficient not only for evaluation of immediate threats, but also will contribute to the research of long-term mercury distribution trends.

From this research, it was concluded that after significant mercury spill, as illustrated by the Spilve street case, return to background concentrations can take as long as several years even after cleanup. One side-observation, obtained during the numerous measurement sessions, is that people quite frequently do not care to verify after the cleanup efforts after mercury spills, if their actions achieved the desired result.

The mercury concentration in the water resources in Latvia had been monitored already for some period of time, but the resolution of such observations seems to be limited. [32] gives the following values on a yearly basis: $<0.2 \mu \mathrm{g}$ in 2010, $<1 \mu \mathrm{g}$ in $2009,1 \%-6 \%$ of $1 \mu \mathrm{g}$ in $2008,3 \%-7 \%$ of $1 \mu \mathrm{g}$ in $2007,5 \%-13 \%$ of $1 \mu \mathrm{g}$ in 2006 . The scientific publications, related to research of mercury pollution in natural waters in Latvia, mainly are discussing mercury concentration in fish and sediments [33] and attention had been paid to mercury in the Baltic Sea and the Gulf of Riga [34], but they seldom contain data about mercury concentrations in the water itself. The Daugava river plume zone [35] (mercury concentrations published only for sediments), Ķī̌sezers [36] (not exactly a scientific paper) and Liepaja port [37] (mercury concentrations published only for sediments) have been investigated.

The highest determined mercury concentration in natural waters measured within the scope of this research was $5.6 \mathrm{ng} / \mathrm{l}$. Though the set of water resources tested does not represent all significant lakes and rivers, it gives an insight into approximate values of $\mathrm{Hg}$ background level in natural waters of Latvia.

The Hg concentrations measured in air and water samples are small, which allows saying that the nature in Latvia is not too much polluted with mercury, and current pollution spots are of a rather local nature.

$\mathrm{Hg}$ concentration long-term trend determination from $\mathrm{Hg}$ measurements in peat is not very conclusive, but still it suggests that Latvia follows the general trend of $\mathrm{Hg}$ concentration increase with the onset of the industrialization period. This illustrates the global nature of mercury as a pollutant [38], which is distributed by natural processes all over the world.

\section{ACKNOWLEDGMENTS}

The work was partly supported by ESF project No. 2009/0210/1DP/1.1.1.2.0/09/APIA/VIAA/100 and EU FP7ENV-2010 project "Global Mercury Observation System" (GMOS, Grant Agreement Number 265113).

Authors express their gratitude to the Faculty of Geography and Earth Sciences of the University of Latvia for the provision of bog peat samples and their age data.

\section{REFERENCES}

1. Lambertsson, L. Mercury species transformations in marine and biological systems studied by isotope dilution mass spectrometry and stable isotope tracers. Ph.D. thesis (summary). Umeå: Umeå University, 2005, 38 p.

2. Lindberg, S., Bullock, R., Ebinghaus, R., et al. A Synthesis of Progress and Uncertainties in Attributing the Sources of Mercury in Deposition. AMBIO: A Journal of the Human Environment, 2007, vol. 36 , issue 1, p. 19-33.

3. Kentisbeer, J., Leaver, D., Cape, JN. An analysis of total gaseous mercury (TGM) concentrations across the UK from a rural sampling network. Journal of environmental monitoring: JEM, 2011, vol. 13(6), p. $1653-1661$.

4. Communication from the Commission to the European Parliament and the Council, on the review of the Community Strategy Concerning Mercury. Brussels, 7.12.2010, COM(2010) 723 final. [Online, accessed 01.11.2011.] Available: http://eur-lex.europa.eu/LexUriServ/ LexUriServ.do?uri=COM:2010:0723:FIN:EN:PDF

5. Darba aizsardzības prasības saskarē ar ķīmiskajām vielām darba vietās, Ministru kabineta noteikumi Nr.325, 15.05.2007. Latvijas Vēstnesis 80 (3656), 18.05.2007. (ar grozijumiem līdz 01.02.2011, MK noteikumiem Nr.92.) (in Latvian) [Online, accessed 02.11.2011] Available: http://www.likumi.lv/doc.php?id=157382

6. Noteikumi par gaisa kvalitāti, Ministru kabineta noteikumi Nr.1290, 03.11.2009. Latvijas Vēstnesis 182 (4168), 17.11.2009. (in Latvian) [Online, accessed 02.11.2011] Available: http://www.likumi.lv/doc.php? id=200712

7. Mirlean, N., Larned, S.T., Nikora, V., et al. Mercury in lakes and lake fishes on a conservation-industry gradient in Brazil, Elsevier, Chemosphere, 2005, vol. 60, p. 226-236.

8. Peckenham, J.M., Kahl, J.S., Mower, B., Background mercury concentrations in river water in Maine, U.S.A., Environmental Monitoring and Assessment, 2003, vol. 89(2), p. 129-152.

9. Noteikumi par virszemes un pazemes üdeņu kvalitāti, Ministru kabineta noteikumi Nr.118, 12.03.2002. Latvijas Vēstnesis 50 (2625), 03.04.2002. (ar grozījumiem līdz 22.12.2009, MK noteikumiem Nr.1632.) (in 


Latvian) [Online, accessed 02.11.2011] Available:
http://www.likumi.lv/doc.php?id=60829

10. Sholupov, S., Pogarev, S., Ryzhov, V., Skudra, A., Bogans, E. Zeeman AA Monitors for Determination of Background Mercury Concentration in Ambient Air and Gases without Absorption Traps. In: Proceedings of 15th International Conference on Heavy Metals in the Environment (15th ICHMET), Gdansk, Poland, September 19-23, 2010. p. $259-261$.

11. BS EN 15852:2010 - Ambient air quality. Standard method for the determination of total gaseous mercury.

12. Bogans, E., Gavare, Z., Skudra, A., et al. Mercury determination in air. In: International Conference EcoBalt 2005, Riga, Latvia, May 5 -6, 2005. Abstracts Riga, 2005, p. 27-28.

13. Bogans, E., Briedis, S., Gavare, Z., et al. Mercury pollution determination in Riga. In: International Conference EcoBalt 2006, Riga, Latvia, May11-12, 2006. Abstracts Riga, 2006, p. 71-72.

14. Gavare, Z., Bogans, E., Skudra, A., et al. Mercury pollution determination in Riga by Zeeman Atomic Absorption Spectroscopy. In: 2007 European Winter Conference on Plasma Spectrochemistry, Taormina, Italy, February 18-23, 2007. Abstracts Taormina, 2007, abstract number TuPo60.

15. Gavare, Z., Bogans, E., Skudra, A., et al. Mercury pollution surveys in Riga (Latvia). In: 11th Workshop on Progress in Analytical Methodologies for Trace Metal Speciation, Munster, Germany, September 4-7, 2007. Abstracts Munster, 2007, abstract \#78.

16. Gavare, Z., Bogans, E., Švāgere, A. Mercury pollution surveys in Riga by Zeeman atomic absorption spectroscopy. Latvian Journal of Physics and Technical Sciences, 2008, Nr.3, p. 34-42.

17. Bogans, E., Gavare, Z., Skudra, A. Mercury pollution surveys in urban area of Riga (Latvia). In: 9th International Conference on Mercury as a Global Pollutant. Guyiang, China, June 7-12, 2009. Abstracts Guyang 2009, S18-42, v.18,.p.48.

18. "Starp dzīvojamām mājām bija izlijis dzīvsudrabs", Leta, 17.06.2005. (in Latvian) [Online, accessed 03.11.2011.] Available: http://www.tvnet.lv/zinas/kriminalzinas/285250-starp_dzivojamam_ majam_bija_izlijis_dzivsudrabs

19. Методика выполнения измерений массовой кониентрации общей ртути в пробах природных, питьевых, поверхностных, морских и очищенных сточных вод атомно-абсорбчиионным методом с Зеемановской коррекиией неселективного поглощения на анализаторе ртути РА-915+ с приставкой РП-91. Аттестована ФГУП «ВНИИМ им. Д. И. Менделеева», фирма «ЛЮМЭКС», С.Петербург, 2007 год (in Russian)

20. Методика выполнения измерений массовой концентрации общей ртути в пробах природной, питьевой и сточной воды методом «холодного пара» на анализаторе ртути РА-915+ с приставкой РП-91. Государственный комитет Российской Федерации по охране окружающей среды, Москва, 2004 год (in Russian)

21. Лапердина, ТГ. Определение ртути в природных водах. Новосибирск: Наука, 2000. 222 с. (in Russian)

22. Intra-laboratory evaluation of suitability of different pretreatment methods, unpublished.

23. Analytical Detection Limit Guidance \& Laboratory Guide for Determining Method Detection Limits. Wisconsin Department of Natural Resources Laboratory Certification Program, 1996, 24 p.

24. Leopold, K., Foulkes, M., Worsfold, P. Methods for the determination and speciation of mercury in natural waters - A review. Anal. Chim. Acta, 2010, vol. 663, p.127-138.

25. Steinnes, E., Sjobakk, T.E. Order-of-magnitude increase of $\mathrm{Hg}$ in Norwegian peat profiles since the outset of industrial activity in Europe. Environmental Pollution, 2005, vol. 137, p. 365-370

26. Biester, H., Kilian, R., Franzen, C., et al. Elevated mercury accumulation in a peat bog of the Magellanic Moorlands, Chile $\left(53^{\circ} \mathrm{S}\right)-$ an anthropogenic signal from the Southern Hemisphere. Earth and Planetary Science Letters, 2002, vol. 201, p. 609-620.

27. Roos-Barraclough, F., et al. A 14500 year record of the accumulation of atmospheric mercury in peat: volcanic signals, anthropogenic influences and a correlation to bromine accumulation. Earth and Planetary Science Letters, 2002, vol. 202, p. 435-451.

28. Landis, M.S., Vette, A.F., Keeler, G.J. Atmospheric mercury in the Lake Michigan basin: influence of the Chicago/Gary urban area. Environmental science technology, 2002, vol. 36, No. 21, p. 4508-4517.

29. Sheu, G.R., Mason, R.P., Lawson, N.M. Speciation and distribution of atmospheric mercury over the northern Chesapeake Bay. ACS
Symposium Series, Chemicals in the Environment, 2002, Vol. 806, Chapter 12, p. 223-242.

30. Dommergue, A., Ferrari, C.P., Planchon, F.A., et al. Influence of anthropogenic sources on total gaseous mercury variability in Grenoble suburban air (France). Science of the Total Environment, 2002, vol. 297(1-3), p. 203-213.

31. Vides monitoringa programma. Gaiss, ūdens, zeme, biologiskā daudzveidība. Rīgā, 2010. (in Latvian) [Online, accessed 03.11.2011.] Available: http://www.meteo.lv/public/30839.html

32. Pārskati par virszemes ūdens kvalitātes stāvokli Latvijā, Latvija vides, ǵeologijas un meteoroloǵijas centrs. (in Latvian) [Online, accessed 03.11.2011.] Available: http://www.meteo.lv/public/30578.html

33. Deksne, R., Teirumnieka, Ē. Smago metālu piesārņojuma līmenis Rēzeknes un Ludzas rajona ezeru ūden̄̄ un zivīs. Daugavpils Universitātes 50. starptautiskās zinātniskās konferences materiāli, Daugavpils, Saule, 2009, 134 lpp. (in Latvian)

34. Leivuori, M., Jokšas, K., Seisuma, Z., et al. Distribution of heavy metals in sediments of the Gulf of Riga, Baltic Sea. Boreal Environment Research 5, Helsinki, 19 June 2000, p.165-185.

35. Seisuma, Z., Kulikova, I. Behavior of $\mathrm{Hg}, \mathrm{Cu}, \mathrm{Zn}, \mathrm{Mn}$ and $\mathrm{Fe}$ in the Daugava plume zone (Gulf of Riga, Baltic Sea). PSP Fresenius Environmental Bulletin, Volume 11 - No 2. 2002, p. 67 - 73.

36. Ķ̌̄̌sezera un tā sateces baseina vides raksturojums, ezera piesārņojuma avotu identifikācija un ekologiskais novērtējums. SIA "E-Daugava" pētījums pēc Rīgas pilsētas Vides departamenta pasūtījuma, 2005. (in Latvian) [Online, accessed 04.11.2011.] Available: http://www.sus.lv/files/kisezers.doc

37. Kulikova, I., Seisuma, Z., Jansons, M. An Assessment of Metal Pollution in the Liepaja Harbour (Baltic Sea), PSP Fresenius Environmental Bulletin, Volume 12 - No. 8 - 2003, p. 906-913.

38. Pirrone, N., Mason, R. Mercury Fate and Transport in the Global Atmosphere: Emissions, Measurements and Models. USA: Springer (ISBN: 978-0-387-93957-5), 2009, $637 \mathrm{p}$

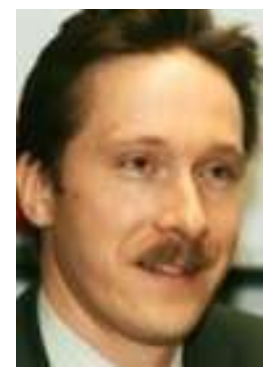

Egils Bogans, M.Sc., researcher, Institute of Atomic Physics and Spectroscopy, University of Latvia. E. Bogans in 2005 graduated Faculty of Physics and Mathematics (University of Latvia) with M.Sc. degree in physics and currently is working on his doctoral thesis. His research interests are centered on spectroscopic techniques used in mercury analysis and their practical applications for mercury determination, particularly - in air. $\mathrm{He}$ is a researcher at Institute of Atomic Physics and Spectroscopy, University of Latvia, Riga, Latvia. He has participated in different local and international projects related to mercury pollution determination.

Address: Škūn̄u str. 4, LV-1050, Riga, Latvia

Phone: +371 67225907, Fax: +37167225039

E-mail: egils.bogans@gmail.com

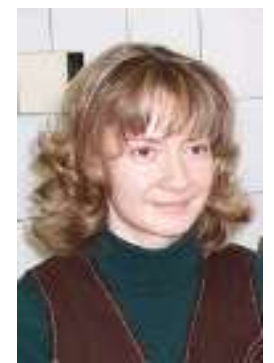

Zanda Gavare, Dr. phys., researcher, Institute of Atomic Physics and Spectroscopy, University of Latvia.

Z. Gavare defended her PhD Thesis "Spectroscopic diagnostics of low-temperature gas-discharge plasma" in Faculty of Physics and Mathematics, University of Latvia (2010). She works at the Institute of Atomic Physics and Spectroscopy since 2002. Her research interests are spectroscopic diagnostics of low-temperature high-frequency plasma and mercury concentration determination techniques in liquids. She has participated in different Latvian and International projects related to plasma spectroscopy and mercury pollution determination. Z. Gavare is co-author of 12 scientific papers.

Address: Šḳūṇu str. 4, LV-1050, Riga, Latvia

Phone: +371 67225907, Fax: +37167225039

E-mail: zanda.gavare@gmail.com 


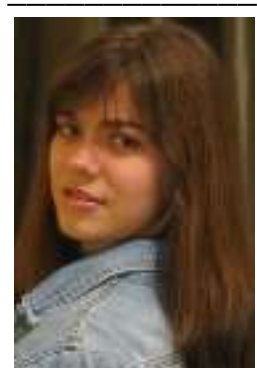

Anda Švāgere, M.Sc. in physics, scientific assistant, Institute of Atomic Physics and Spectroscopy, University of Latvia.

After obtaining her master's degree in summer 2011, A. Švāgere has recently started her doctoral studies in University of Latvia. Her major research areas are methods for mercury analysis in liquids and solids, and spectroscopic analysis of light sources. A. Švāgere works in Institute of Atomic Physics and Spectroscopy, Laboratory of High-resolution Spectroscopy and Light Source Technology, Riga of since 2006 when she came there as a bachelor

student.

Address: Šḳūnu str. 4, LV-1050, Riga, Latvia

Phone: +371 67225907, Fax: +371 67225039

E-mail: anda.svagere@gmail.com

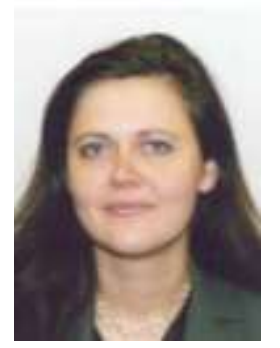

Rita Poikāne, Dr. chem., researcher, Latvian Institute of Aquatic Ecology and Institute of Atomic Physics and Spectroscopy at University of Latvia. Since 2006 Rita Poikane has researcher position in the Latvian Institute of Aquatic Ecology, since 2009 - researcher position in Institute of Atomic Physics and Spectroscopy. The main research area is hazardous substances in the aquatic environment, ecological and chemical status of waters - inland and marine. She has participated in numerous local and international projects related to Water Framework Directive and National monitoring program implementation, the control of hazardous substances and the research of nutrient and hazardous substances dynamics in the aquatic ecosystem. Doctoral theses "The Role of Suspended Particulate Matter and Sediment in the Dynamics of Metals in the Gulf of Riga" was defended in University of Latvia, Riga (2008)

Address: LIAE, Daugavgrīvas 8, Riga, LV-1007, Latvia; IAPS, Šķūņu 4., LV1050, Riga, Latvia;

Phone:+371 67614840, Fax: +371 67601995

E-mail: rita.poikane@lhei.lv

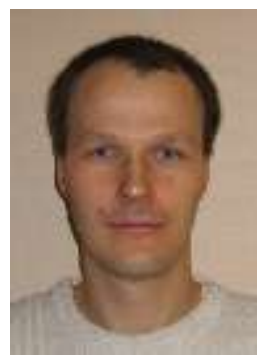

Jānis Skudra, student, Institute of Atomic Physics and Spectroscopy, University of Latvia. Production and development of high frequency electrodeless discharge lamps.

J. Skudra is currently working in European Social Fund project "Spectrometric techniques for detection of heavy metal contaminants" as programming engineer in Institute of Atomic Physics and Spectroscopy, University of Latvia. His main duty is software development for data processing and automation of measurements.

J. Skudra is also involved in production process of electrodeless discharge lamps using vacuum device. He is co-author of 9 scientific publications.

Address: Šķūnu str. 4, LV-1050, Riga, Latvia

Phone: +37167225907 , Fax: +371 67225039

E-mail: jsk@one.lv

Egils Bogans, Zanda Gavare, Anda Svagere, Rita Poikane, Jānis Skudra. Dzīvsudraba piesārṇojuma apzināšana Latvijā, izmantojot augstas jūtības Zēmana atomu absorbcijas spektrometru

Dż̄vsudrabs ir kaitīgs gan videi, gan cilvēku veselībai, tādēl ir svarīgi apzināt tā avotus. Viens no veidiem, kā var spriest par dzīvsudraba apriti dabā un par tā „paradumiem”, ir monitorings. Šajā darbā sniegts ieskats par Hg koncentrācijas mērijumiem Latvijā.

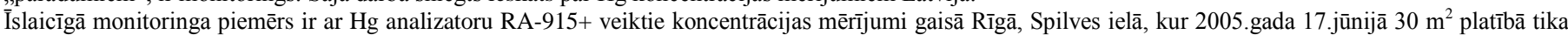
izliets $0,5 \mathrm{~kg}$ dzīvsudraba. No 2005. līdz 2011.gadam veikti 9 mērījumi, kas ataino koncentrācijas izmaiņas šajā laika posmā. Neraugoties uz to, ka neilgi pēc notikuma tika ziņots par izlietā dz̄̄vsudraba savākšanu, iegūtie dati liecina, ka dzīvsudraba piesārṇojums ir ilgstoša problēma, ar kuru nemaz tik viegli nav tikt galā.

Ar analizatora un palīgiekārtas RP-91 palīdzību veikti Hg koncentrācijas mērījumi vairāku Latvijas upju un ezeru ūdenos. Ūdenu kontrole ir svarīga, jo galvenokārt tieši tur norisinās dzīvsudraba metilācija, savukārt metildzīvsudrabs akumulējas ūdens iemītniekos un nokḷūst barības ķēdē, tādējādi uzkrājoties un sasniedzot veselībai kaitīgas koncentrācijas. Mūsu veiktajos mērījumos iegūtās vērtības bija nelielas un nepārsniedza likumā noteiktās.

Izmantojot RA-915+ un palīgiekārtu RP-91C veikti mērījumi divos Latvijas ombrotrofajos jeb augstajos purvos - Dižajā Veikeniekā un Dzelvē. Ombrotrofie purvi ir īpaši ar to, ka dzīvsudrabs tajos nonāk tikai kopā ar nokrišņiem, jo šiem purviem nav saskares ar gruntsūdeņiem. Mērot Hg koncentrācijas sadalījuma pa kūdras dziļumu, un nosakot kūdras slānim atbilstošo vecumu, iegūti grafiki, kas ataino Hg koncentrācijas izmaiṇu vēsturi atmosfêrā gadu gaitā. Šādi mērījumi ir ilglaicīgā monitoringa piemērs, jo aptver vairāk kā tūkstoš gadus.

Lìdz šim gaisā, augsnē un ūdeņos veiktie mērījumi uzrāda samērā nelielas koncentrācijas, kas ḷauj domāt, ka Latvijas vide nav īpaši piesārṇota ar dzīvsudrabu, tomēr tas nav iemesls, lai par to aizmirstu. Iegūtie dati ir vērtīgi un noderīgi gan $\mathrm{Hg}$ monitoringam, gan lai pētītu un izprastu likumsakarības Hg apritei dabā.

Эгилс Боганс, Занда Гаваре, Анда Швагере, Рита Пойкане, Яанис Скудра. Обследование загрязнения ртутью в Латвии с использованием чувствительного Земановского атомно-абсорбционного спектрометра

Ртуть вредна для окружающей среды и здоровья человека, поэтому важно выявить её источники. Мониторинг является одним из способов, с помощю которого можно судить о движении ртути в природе и её "привычках". Эта статья дает взгляд в измерения концентрации ртути в Латвии.

Как пример краткосрочного мониторинга приведены измерения концентрации Hg с использованием анализатора RA-915 + в воздухе в Риге, на улице Спилвес, где 17 июня 2005 года на площади $30 \mathrm{~m}^{2}$ было вылито 0,5 кг ртути. С 2005 по 2011 год проведено девять измерений, которые отражают изменения концентрации в этот период. Несмотря на то, что вскоре после происшествия было объявлено о сборе пролитой ртути, данные показывают, что загрязнение ртутью является продолжительной проблемой, которую не так-то просто решить.

Используя анализатор и приставку RP-91, проведены измерения концентрации ртути в воде нескольких латвийских рек и озёр. Контроль воды важен потому, что как раз там в основном происходит метиляция ртути, а метиловая ртуть накапливается по пищевой иерархии, достигая опасных для здоровья концентраций. Значения, полученные в наших измерениях, были небольшими и не превышали установленные нормативы.

Используя RA-915 + и приставку RP-91C, измерялось содержание ртути в торфе двух латвийских омбротрофных болот - Dižais Veikenieks и Dzelve. Омбротрофные болота примечательны тем, что ртуть туда попадает только посредством осадков, так как эти болота не находятся в контакте с грунтовыми водами. Измеряя распределение концентрации Нg по глубине торфа и определяя возраст соответствующего слоя торфа, можно получить историю изменений концентрации ртути в атмосфере на протяжении многих лет. Такие измерения являются примером долгосрочного мониторинга, так как охватывают более тысячи лет.

Измерения, проведённые в воздухе, почве и воде, показывают относительно низкие концентрации, что позволяет предположить, что среда в Латвии пока не загрязнена ртутью, но это не повод забывать об этом. Собранные данные являются полезными для мониторинга ртути и для исследования закономерностей движения ртути в природе. 